periods of fasting. Their reaction to feeding is much less pronounced than that of the other non-mucous gland cells. The cells of the intestinal epithelium are easily brought to the resting stage by short periods of fasting, and become strongly sensitized to the subsequent administration of food ; their eytoplasmic inclusions show profound morphological changes mmediately upon direct contact with food $(a, b, c$ a illustration). Marked changes in the Golgi material in the upper part and their gradual decline and total disappearance in the posterior part of the small intestine are no doubt connected with the functions of the different parts of the intestinal lining.

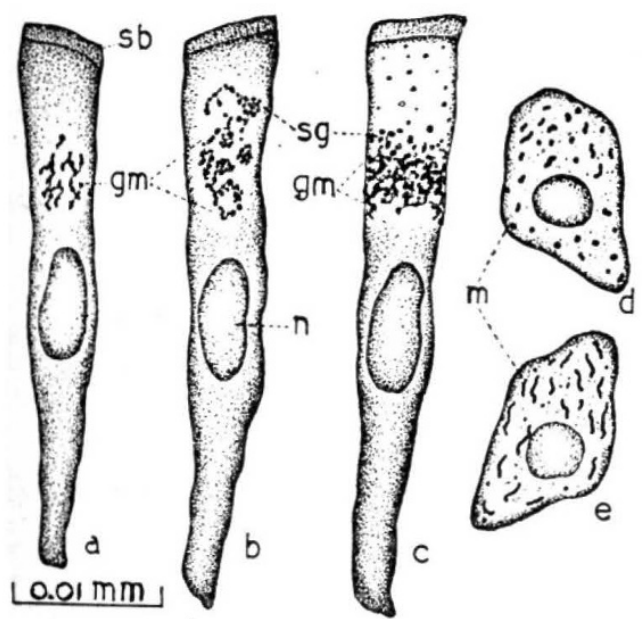

$a, b, c$. Cells of the DUODENOM OF THE FOWL, SHowing Golgi MATERIAL: (a) AFTER 24 HOURS FAST; (b) AFTER FEEDING, UPON DIREOT CONTACT WITH FOOD ; $(c)$ ONE HOUR AFTER FEEDING. $d, e$. CELLS OF THE LIVER OF FOWL, SHOWING MITOCHONDRIA: (d) AFTER 24 HOURS FAST; (e) TWO HOURS AFTER FEEDING $g m$., Golgi material : m., mitochondria ; $n$., nucleus; $8 g$. , secretory granules; sb., striated border

Although the final product of activity varies in different types of cell, certain constant morphological changes always accompany its production. The Golgi material always shows marked changes under different physiological conditions, and the final elaboration of secretory granules always takes place in the Golgi field. Hypertrophy of the Golgi material and its increased power to reduce osmium tetroxide during cellular activity in the upper part of the alimentary tract shows that the Golgi material actively participates in secretory phenomena, and that it is not a structure with permanent form, but is a specific substance which appears in different forms depending on the functional stage of the cell. The changes in the mitochondria do not suggest their direct participation in secretion. They are least marked in the pancreas and most striking in the liver cells, and are concerned almost exclusively with their orientation in the cell ( $d, e$ in illustration). It is highly probable that the changes undergone by these cell components are more a reflexion of cell activity, as Pollister ${ }^{4}$ assumes, than of their direct participation in the secretory process.

It is hoped to publish a more detailed account of this work.

Department of Zoology,

K. S. CHODNIK

University of Edinburgh.

${ }^{1}$ Argeseanu, S., and May, R. M., Arch. Anat. Micr., 34 (1938).

"Dalton, A. J., Anat. Rec., 58 (1933).

s Hibbard, A., J. Morph., 70 (1942).

4 Pollister, A. W. Phys. Z., 14 (1941).

\section{Hæmagglutinins of the Hæmophilus Group}

WE have observed that the erythrocytes of man, mouse, fowl and other animals are agglutinated by saline suspensions of Hoemophilus pertussis, parapertussis and bronchisepticus, and also by filtrates and supernates of casein digest broth cultures of these organisms. The effect is neutralized by human and animal immune sera. A characteristic rise and fall in anti-hæmagglutinin titre occurs in the sera of children during the course of whooping cough. The protective power of sera, given parenterally, against lethal intranasal doses of $H$. pertussis in mice is closely correlated with their anti-hæmagglutinin titres, but not with their content of bacterial agglutinin or antitoxin.

Freshly isolated strains of $H$. pertussis are rich in hæmagglutinin; but the content falls, more or less rapidly, on repeated subculture, even though there is no change in phase, as judged by bacterial agglutination. There is a close correlation between the hæmagglutinin content of strains, their virulence for mice by the intranasal route, and the antigenic potency of vaccines prepared from them in experimental murine pertussis. Virulent hæmolytic strains of $H$. bronchisepticus are rich in hæmagglutinin, which is not present in the avirulent, non-hæmolytic variants.

Bacteria-free filtrates or supernates of broth cultures of $H$. pertussis, with adequate hæmagglutinin content, immunize mice against intranasal infection as efficiently as do vaccines prepared from the washed and re-suspended organisms, or from cultures on Bordet-Gengou medium. The hæmagglutinin in such filtrates, however, is labile and is not converted into toxoid by formalin.

Details of the experiments on which the foregoing statements are based will shortly be published; the fact that field trials of various whooping cough vaccines are at present in progress has prompted this note.

Saline extracts of smooth strains of Hcemophilus influenzce contain a substance which is adsorbed to erythrocytes. This substance does not cause the red cells to agglutinate, but cells treated with it are specifically agglutinated by therapeutic sera prepared by immunization of rabbits with smooth strains of $H$. influenzoe. The substance is not the toxin described by Dubos $^{1}$, since it is obtainable only from smooth strains, whereas Dubos found ${ }^{2}$ (we have confirmed his finding) that the toxin can be extracted from the rough variants also. Red cells exposed to solutions of the type-specific polysaccharide of Type $B$ are not agglutinated by Type $B$ immune sera, but absorption of Type $B$ sera with the polysaccharide removes their power of agglutinating erythrocytes treated with saline extracts. The fraction in saline extracts of $H$. influenza which is adsorbed to erythrocytes appears to be, therefore, a combination of the specific polysaccharide with some other substance.

Erythrocytes which have been exposed to this fraction of $H$. influenzae are no longer agglutinable by suspensions of influenzal virus in the Hirst test, or by the hæmagglutinin of $H$. pertussis.
E. V. KEOGH
E. A. North
M. F. WARBURTON

Commonwealth Serum Laboratories, Melbourne. April 14.

' Dubos, R. J., J. Bact., 43, 77 (1942).

'Dubos, R. J., personal communication (1947). 